Maurer School of Law: Indiana University

Fall 1999

\title{
How Is International Human Rights Law Enforced?
}

Harold Hongju Koh

Yale Law School

Follow this and additional works at: https://www.repository.law.indiana.edu/ilj

Part of the Human Rights Law Commons, International Law Commons, and the Law Enforcement and Corrections Commons

\section{Recommended Citation}

Koh, Harold Hongju (1999) "How Is International Human Rights Law Enforced?," Indiana Law Journal: Vol. 74 : Iss. 4 , Article 9.

Available at: https://www.repository.law.indiana.edu/ilj/vol74/iss4/9

This Lecture is brought to you for free and open access by the Law School Journals at Digital Repository @ Maurer Law. It has been accepted for inclusion in Indiana Law Journal by an authorized editor of Digital Repository @ Maurer Law. For more information, please contact rvaughan@indiana.edu.

\section{$\Psi$}

JEROME HALL LAW LIBRARY

INDIANA UNIVERSITY

Maurer School of Law
Blooming toan 


\title{
How Is International Human Rights Law Enforced? ${ }^{\dagger}$
}

\author{
Addison C. Harris Lecture \\ January 21, 1998 \\ HAROLD HONGJU KOH*
}

I am greatly honored to deliver this distinguished Lecture, particularly given the illustrious list of lecturers who have preceded me to this podium. ${ }^{1} \mathrm{My}$ own path to this podium began in Washington, D.C., where as a private lawyer I specialized in issues of international business and trade law: what most American law schools now think of as "international business transactions." But even while working on these matters, I became increasingly diverted toward the novel, growing field of international human rights. While in private practice in the early $1980 \mathrm{~s}$, I became involved in the representation of the American hostages who had been held for 444 days in the U.S. embassy in Tehran. ${ }^{3}$ Once starting an academic career, I took occasional forays into international human rights advocacy, ${ }^{4}$ but my main focus remained on the law of international business transactions and United States foreign policy, two examples of what Henry Steiner and Detlev Vagts have felicitously dubbed "Transnational Legal Problems."

† 1999 Harold Hongju Koh.

* Gerard C. and Bemice Latrobe Smith Professor of International Law and Director, Orville H. Schell, Jr. Center for International Human Rights, Yale Law School (on leave), Assistant United States Secretary of State, Democracy, Human Rights and Labor. These remarks were originally delivered as the January 1998 Addison Harris Lecture at the University of Indiana School of Law-Bloomington. They grow out of a chapter in a forthcoming book entitled Why Nations Obey: A Theory of Compliance With International Law, which I am writing under the auspices of the Century Foundation and the Guggenheim Foundation. This Lecture also shares thoughts with my 1998 Frankel Lecture at the University of Houston Law Center, Houston, Texas, and the 1997 Waynflete Lectures at Magdalen College, Oxford University. I am deeply grateful to Dean Alfred Aman, Acting Dean Lauren Robel, Dean Kelly Townes, Professor David Williams, the Harris Lecture Speaker's Committee, and the Editors of the Indiana Law Journal for their enormous hospitality while I was in Hoosier country.

Not long after delivering this Lecture, I was nominated and confirmed as Assistant Secretary for Democracy, Human Rights and Labor in the Clinton Administration. These lightly edited remarks, which have been footnoted for publication, obviously represent only my own views, and not necessarily those of the United States Department of State.

1. Past Harris lecturers include my former Harvard professors Paul Bator and Charles Fried, as well as my current Yale colleagues Guido Calabresi, Owen Fiss, Jules Coleman, and Robert Gordon.

2. See generally Harold Hongju Koh, International Business Transactions in United States Courts, 261 ReCueI DES CoURS 13 (1996).

3. See Persinger v. Islamic Republic of Iran, 729 F.2d 835 (D.C. Cir. 1984).

4. See, e.g., David Cole et al., Interpreting the Alien Tort Statute: Amicus Curiae Memorandum of International Law Scholars and Practitioners in Trajano v. Marcos, 12 HASTINGS INTL \& COMP. L. REV. 1 (1988).

5. See generally HENRY J. STEINER ET AL., TRANSNATIONAL LEGAL PROBLEMS (4th ed. 1994). 
As this decade began, international human rights law became the primary focus of both my theoretical and academic work, when I became involved with my students in a number of lawsuits in U.S. courts against human rights violators. In 1992, my students and I brought suits on behalf of the Haitian and Cuban refugees against the U.S. government ${ }^{6}$ and a number of lawsuits against foreign human rights violators who had come to the United States-the former Guatemalan Minister of Defense, the former dictator of Haiti, an Indonesian general responsible for the 1991 Dili massacre in East Timor, and most recently a suit that is still ongoing in the Southern District of New York against Radovan Karadzic, the leader of the Bosnian Serbs. ${ }^{7}$

In each of these legal lives, as a scholar and a lawyer, I have asked the question that titles this Lecture, namely, "How is International Human Rights Law Enforced?" I wouldn't be surprised if many of you hearing that question were to give a pessimistic answer: international human rights law is not enforced, you might say. Just take a look at the massive human rights violations in Bosnia, violations that have gone unredressed in Cambodia and Iraq; the continuing crises in the Congo, Sierra Leone, Algeria, and Burundi. Look at indicted war criminals, like Radovan Karadzic in Republica Srpska, who continue to flout the jurisdictions of the Bosnian war crimes tribunal. Look, you might say, at the world's willingness to overlook human rights violations committed by more powerful nations, such as Russia's activities in Chechnya, or China's continuing repression after Tienanmen Square. International human rights law is not enforced, you might say, because human rights norms are vague and aspirational, because enforcement mechanisms are toothless, because treaty regimes are notoriously weak, and because national governments lack the economic self-interest or the political will to restrain their own human rights violations. So if the question is "how is international human rights law enforced?", many of you might answer: "not at all, or hardly at all." If you hold to this common, skeptical view of human rights enforcement, you would say that international human rights law is not enforced, like "real" domestic law; instead, it is only occasionally "complied with," by nation-states acting out of transparent convenience or self-interest.

In this Lecture, let me take a somewhat different tack, asking first, "What do we mean when we say that any laws are enforced?" Are any laws perfectly enforced? Even here in Bloomington, Indiana, the height of civilization, are the parking laws or burglary laws perfectly enforced? of course, you would concede, parking violations occur here in Bloomington, and burglaries occur, perhaps even daily;

6. See Cuban-American Bar Ass'n v. Christopher, 43 F.3d 1413 (11th Cir. 1995); Haitian Ctrs. Council, Inc. v. McNary, 969 F.2d 1326 (2d Cir. 1992), vacated as moot sub nom. Sale v. Haitian Ctrs. Council, Inc., 509 U.S. 155 (1993); Haitian Ctrs. Council, Inc. v. Sale, 823 F. Supp. 1028 (ED.N.Y. 1993). For an account of these cases, written by three of my students, see Victoria Clawson et al, Litigating as Law Students: An Inside Look at Haitian Centers Council, 103 YALE L.J. 2337 (1994).

7. See Xuncax v. Gramajo, 886 F. Supp. 162 (D. Mass. 1995); Todd v. Panjaitan, No $92-$ 12255WD (D. Mass. decided Oct. 25, 1994) (\$14 million judgment awarded); Doe v. Karadzic, 886 F. Supp. 734 (S.D.N.Y. 1994), rev'd sub nom. Kadic v. Karadzic, 70 F.3d 232 (2d Cir. 1995); Paul v. Avril, 812 F. Supp. 207 (S.D. Fla. 1993) (\$41 million judgment awarded); Ortiz v. Gramajo, No. 91-11612WD (D. Mass. filed Sept. 17, 1992) (\$47.5 million judgment awarded). 
sometimes egregiously. But those facts alone hardly mean that there is no enforcement of laws against parking violations or burglary. Here in Indiana, the laws against burglary may be underenforced, they may be imperfectly enforced, but they are enforced, through a well-understood domestic legal process of legislation, adjudication, and executive action. That process involves prosecutors, statutes, judges, police officers, and penalties that interact, interpret legal norms, and work to internalize those norms into the value sets of citizens like ourselves.

But if we are willing to give that answer to the question "how is domestic law enforced?", why not similarly answer the question whether international human rights law is enforced? In this Lecture, I will argue that in much the same way, these international norms of international human rights law are underenforced, imperfectly enforced; but they are enforced through a complex, little-understood legal process that I call transnational legal process. As I have elaborated in other writing, ${ }^{8}$ for shorthand purposes, transnational legal process can be thought of in three phases: the institutional interaction whereby global norms of international human rights law are debated, interpreted, and ultimately internalized by domestic legal systems. To claim that this complex transnational legal process of enforcing international human rights law via interaction, interpretation, and internalization exists is not to say that it always works or even that it works very well. As I will be the first to concede, this process works sporadically, and that we often most clearly see its spectacular failures, as in Cambodia, Bosnia, and Rwanda. But the process of enforcing international human rights law also sometimes has its successes, which gives us reason not to ignore that process, but to try to develop and nurture it. Just as doctors used early successes in addressing polio to push our understanding of how the prevention and healing process works, lawyers can try to globalize the lessons of human rights enforcement. So if the question is "how is international human rights enforced?", my short answer is through a transnational legal process of institutional interaction, interpretation of legal norms, and attempts to internalize those norms into domestic legal systems.

With that introduction, let me divide the balance of these remarks into two parts: First, how, in theory, does transnational legal process promote national obedience of international human rights law? Second, how does transnational legal process-this process that I call "interaction, interpretation and internalization" - work in real cases?

\section{The Theory of TransNational Legal Process}

The first question, why do nations obey international human rights law, is really a sub-set of a much broader question: why do nations obey international law of any kind? That timeless question, which has troubled thinkers over historical eras dating back to the Roman Empire, is the subject of a book I am writing, under the title

8. For fuller discussion of transnational legal process, see Harold Hongju Koh, Transnational Legal Process, 75 NEB. L. REv. 181 (1996); Harold Hongju Koh, The 1998 Frankel Lecture: Bringing International Law Home, 35 Hous. L. REv. 623 (1998) [hereinafter Koh, Frankel Lecture], and Harold Hongju Koh, Why Do Nations Obey International Law?, 106 YALE L.J. 2599 (1997) [hereinafter Koh, Why Do Nations Obey International Law?]. 
"Why Nations Obey?". My forthcoming book examines both the theoretical and the historical answers to that question.9

\section{A. From Compliance to Obedience}

Let us start by asking what it means to "obey" international law at all. Imagine four kinds of relationships between rules and conduct: coincidence, conformity, compliance, and obedience. For example, I have lived my whole life in the United States; but a few years ago, I took a sabbatical year in England. While there, I noticed that everybody drives on the left side of the road, as a matter of both practice and of law. Yet what is the relationship between the law and the observed practice?

One remote possibility is coincidence. It could be coincidence that the law is that everyone must drive on the left and that in practice everybody follows that norm. Yet coincidence might explain why one person follows a rule, but not why millions of people throughout the country do the same. That suggests a second possibility: conformity. If people know of the rule that you must drive on the left, they may well choose to conform their conduct to that rule when convenient; but feel no obligation to do so when inconvenient. (Perhaps some Scots, for example, swerve over and drive on the right, in remote unpopulated areas of the Hebrides). But, is there a third possibility, compliance? Perhaps people are both aware of the rule and accept the rule for a variety of external reasons, for example, to get specific rewards, to receive insurance benefits, or to avoid certain kinds of bad results, such as traffic tickets, or getting hit by an oncoming car. These are instrumental reasons why someone might decide to comply with a rule even if they felt no moral obligation to obey it. Finally, there is a fourth possibility, obedience: the notion that a person or an organization adopts the behavior that is prescribed by the rule because he or it has somehow internalized that rule and made it a part of their internal value system.

Notice that as we move down this scale from coincidence to conformity to compliance to obedience, we see an increase of what I will call "norminternalization." As you move from grudgingly accepting a rule one time only to habitually obeying it, the rule transforms from being some kind of external sanction to becoming an internal imperative. We see this evolutionary process regularly in our daily lives: when you put on a bicycle helmet; when you snap on your seatbelt; when you recycle a tin can; when you do not smoke in the law school cafeteria. All of these are examples of people moving from conformity with a rule to compliance and gradually obedience, which is driven by a sense of an internalized norm. Over time, we also witness a rise in what one might call "normativity." If you see someone driving $100 \mathrm{mph}$, and then suddenly they see a police car and slow dramatically to $60 \mathrm{mph}$, you might say they are complying with; but not really obeying the speed limit. But, if one witnesses people routinely driving at the speed limit (without witnesses around), or routinely disposing of litter, or recycling without being told, we are seeing an internalized normative form of behavior-an note 8 .

9. For the gist of both answers, see Koh, Why Do Nations Obey International Law?, supra 
increase in normativity, if you will-which derives from the incorporation of external norms or values into a person's or organization's internal value set.

There is a further point as well: namely, that the most effective form of lawenforcement is not the imposition of external sanction, but the inculcation of internal obedience. Most traffic laws, litter laws, tax laws and the like are enforced primarily not by enforcement officers, but by the social internalization of norms of obedience! Indeed, enforcement is maximized when a norm is so widely obeyed that external sanctions become virtually unnecessary. As my Yale colleague Bob Ellickson has demonstrated, when everyone in a community follows certain social norms out of felt internal normativity, order can be maintained without rigid systems of external legal enforcement, because self-enforcement is both more effective and more efficient than third-party controls. ${ }^{10}$ Social psychologists who study why individuals obey the law have reached the same conclusion. ${ }^{11}$

\section{B. The Relationship Between Enforcement and Obedience}

With this background, let us now turn to the question of how international human rights law is enforced, which is a subset of the larger question: why do nations obey international law of any kind? In earlier writing, I have suggested that, over time, five distinct explanations have emerged to answer the question "why nations obey?": power, self-interest or rational choice; liberal explanations based on rule-legitimacy or political identity; communitarian explanations; and legal process explanations at the state-to-state level (what I will call "horizontal" or "international legal process" explanations) and from the international-to-national level (what I will call "vertical" or "transnational legal process explanations"). ${ }^{12}$

In their current form, each of these five approaches gives their own short answer to the question "how is international human rights law enforced?" Let me start with the realists, who date back to Thomas Hobbes, but include such modern-day theorists as George Kennan, Hans Morgenthau, and Henry Kissinger. To the question "why do nations obey international law?", their short answer is power: nations never truly "obey" international law, they only comply with it, because

10. See ROBERT C. ElLICKSON, ORDER WITHOUT LAW: How NeIGHBORS SETME DiSPUIES 132 (1991) ("A person who has 'internalized' a social norm is by definition committed to selfenforcement of a rule ...."); id. at 126 n.8 (1991) ("Whatever the origin of self-enforced moral rules, there is broad agreement that the overall system of social control must depend vitally on achieving cooperation through self-enforcement."); Robert C. Ellickson, Bringing Culture and Human Frailty to Rational Actors: A Critique of Classical Law and Economics, 65 CH.-KRNT L. REV. 23, 44 (1989) (arguing that the primary system of social control is a "first-party system of social control that would operate without external enforcers") (emphasis in original).

11. See, e.g., TOMR TYLER, WHY PEOPLE OBEY THE LAW (1990) (concluding, after extensive empirical study, that people comply with law not so much because they fear punishment as because they feel that legal authorities are legitimate); see also id. at 4 (urging authorities who seek to promote voluntary compliance with laws to apply "[a] normative perspective [which] leads to a focus on people's internalized norms of justice and obligation," rather than "an instrumental perspective [which] regards compliance as a form of behavior occurring in response to external factors").

12. Both the historical and theoretical analysis are fleshed out in Koh, Why Do Nations Obey International Law?, supra note 8, from which this portion of the Lecture derives. 
someone else makes them. Why, for example, why did Iraq ultimately respect the borders of Kuwait? In the end, because the other nations of the world came in and drove Saddam out! Under this view, nations can be coerced or bribed to follow certain rules, or even induced to bargain in the shadow of such incentives. But in the end, the critical factor is neither altruistic or normative, only the realist values of power and coercion. ${ }^{13}$ Thus, the familiar power explanation traces back to Thucydides: the strong states do what they can, the weak states suffer what they must, but in the end there is no real "obedience" of international law, only such coincidence between national conduct and international rules that results from power and coercion.

There is a second, kinder and gentler explanation, based on the self-interest rationales favored by the vibrant school of "rational choice" theory. ${ }^{14}$ Under this explanation, nations may choose rationally to follow certain global rules out of a sense of self-interest. After participating in game-theoretic discussions, to avoid multi-party prisoners' dilemma, nations may decide to cooperate around certain rules, which lead them to establish what international relations theorists call "regimes": governing arrangements in which certain governing norms, rules, and decisionmaking procedures come to predominate because the nations in their longterm self-interests have calculated that they should follow a presumption favoring compliance with such rules.

This "self- interest" rationale helps explains why, for example, complex global rules have emerged in a whole variety of international areas in which nations have established regimes structured around legal rules born of self-interested cooperation. In the contemporary era, for example, talented international relations scholars such as Robert Keohane, Duncan Snidal, and Oran Young have applied increasingly sophisticated rational choice techniques to argue for such an instrumental, interest-based view of international law. Recently, a number of legal scholars, most prominently Kenneth Abbott, Alan Sykes, and John Setear have espoused a similar, "rationalistic" legal vision. Under the rationalist account, participants in a given issue area will develop a set of governing arrangements, along with a set of expectations, rules, and decisionmaking procedures-in other words, a regime-both to restrain the participants and to provide means for achieving their common aims. Within these regimes, international law stabilizes expectations and promotes compliance by reducing transaction costs, providing dispute-resolution procedures, performing signaling functions, triggering negative responses, and promoting information disclosure.

13. The "power" rationale is captured in a famous joke often told about Henry Kissinger, who after he ceased to be the Secretary of State, reportedly went to work as a zoo keeper. After the first day, zoo patrons noticed an amazing phenomenon: that after all of these centuries, the lion was finally lying down with the lamb. The patrons ran excitedly to Dr. Kissinger, and asked, "How have you achieved this miraculous result?" The famous realist replied, "It's simple. A lamb a day!"

14. See, e.g., Kenneth W. Abbott, Modern International Relations Theory: A Prospectus for International Lawyers, 14 YALE J. INT'L L. 335 (1989); Kenneth W. Abbott, The Trading Nation's Dilemma: The Functions of the Law of International Trade, 26 HARV. INT'L L.J. 501 (1985); Kenneth W. Abbott, 'Trust But Verify': The Production of Information in Arms Control Treaties and Other International Agreements, 26 CORNELL INT'L L.J. 1 (1993). 
Recently, more sophisticated instrumentalists have begun to disaggregate the state into its component parts, to introduce international institutions and transnational actors, to incorporate long-term self-interest, and to consider the issue within massively iterated multi-party games. ${ }^{15}$ Subtler instrumentalists even recognize that global rules form part of the environment faced by a state and thus alter the incentives of domestic interest groups and organizations. But even so, their analysis remains thin.

The rationalists recognize nonstate actors as players in the transnational system, but too often ignore them because of the complexity their inclusion adds to their game-theoretic analysis. Nor do these analysts tell much of a domestic politics story, because they tend to operate largely at the horizontal level of the international system. Their chosen issue areas thus tend to be areas like trade and arms control, where nation-states remain the primary players and traditional realist assumptions still largely prevail. Such rationalistic, state-centric theories thus work less well, for example, in such areas as human rights, debt restructuring, or international commercial transactions, where nonstate actors abound, pursue multiple goals in complex nonzero-sum games, and interact repeatedly within institutions nested within broader informal regimes. Rationalists see law as regulating behavior by changing incentives, not altering interests or identities. The role of norms, in their view, is to reduce transactions costs in dynamic interactions among exogenously constituted actors. Shared norms, and the interactive processes by which those norms are interpreted, have little effect on state policies. In effect, they see international law as a kind of mechanical device, a switching mechanism, which facilitates the interactions of autonomous states, not as a communal decisionmaking structure that helps generate options, modify preferences, and build a normative interpretive community.

In short my major complaint about the self-interest explanation is that it does not take account of what I consider to be an important factor-the "vertical" internalization of international norms into domestic legal systems. The rationalists' picture takes too little account of the internalizing, normative, or constitutive impact of participating in the transnational legal process. For the rationalists, the decision to obey the law remains perpetually calculated, never internally felt. Compliance always remains an instrumental computation, never an internalized normative imperative. $^{16}$

This brings me to a third possible explanation for why international human rights laws are enforced, so-called "liberal" theories, which I divide into those scholars who follow principles of "rule legitimacy" and those who focus on national "political identity." Both sets of theorists derive their analysis from Immanuel Kant's pamphlet in 1795, Perpetual Peace. Rule-legitimacy theorists, led by Thomas Franck of NYU, argue that nations do feel some sort of internal "compliance pull" toward certain rules that they feel are legitimate; for example,

15. Duke's Robert Keohane is the leading exemplar of such a sophisticated approach. See Robert O. Keohane, When Does International Law Come Home?, 35 Hous. L. REv. 699 (1998).

16. It would be as if every time you got into a car, you calculated for the first time whether or not to put on a seat belt or to stop for a red light, rather than relying upon internalized norms of obedience. 
the rules against genocide or the rules favoring diplomatic immunity. When nations perceive that rules are legitimate, either because they meet some procedural standard of legitimacy or some substantive notion of due process or distributive justice, they will obey that rule because they are "normatively pulled" toward that rule by its legitimacy. ${ }^{17}$

In my view, this rule-legitimacy approach is problematic because it claims to draw its power from the legitimacy of rules themselves, rather than from communitarian and legal process pressures. In fact, most of us do not litter when others are watching, but not because the no-littering rule itself has such compliance pull, but because of a combination of internal impulse and felt peer pressure. In the same way, Franck's rule-legitimacy ends up being another way of saying that a state obeys a norm because it has been both internalized, and is being enforced by "communitarian peer pressure" (which, I will argue below, is really a form of transnational legal process). ${ }^{18}$

A second view, pressed strongly by other members of this liberal school, argues that whether or not nations comply with international law depends crucially on the extent to which their political identity is based on liberal democracy. This approach derives from a branch of international relations literature known as the "Democratic Peace" literature, pioneered by Michael Doyle of Princeton, my Yale colleague Bruce Russett, and many others who have sought to verify a basic tenet of Kant's writing that liberal democracies do not go to war with each other. The many adherents of this view include President Clinton, who in October of 1995 opined that promoting democracies that participate in the new global marketplace is the right thing to do because we know that these democracies are less likely to go to war.

Transposing this basic maxim to international law; several Harvard theorists, Anne-Marie Slaughter and Andrew Moravcsik, have flipped this maxim, arguing not so much that democracies do not fight each other, but rather, that democracies are more inclined to "do law" with one another. For these analysts, the key variable for whether a nation will or will not obey international law is whether they can be characterized as "liberal". in identity, i.e., having certain democratic attributes such as a form of representative government, civil and political rights, and an independent judicial system dedicated to the rule of law. Not surprisingly, many liberal scholars focus on European Union law, noting that the European system of human rights works because it is largely composed of liberal democracies, who share reasons for collective obedience. This helps explain why, for example, the embryonic African human rights system-a collection of democracies and authoritarian systems-does not work nearly as well.

What is troubling about this view is that it suggests that liberal states interact mainly in a zone of law, while liberal and illiberal states interact in a zone of politics. But in my view, any analysis that treats a state's identity as somehow

17. Franck calls this the "compliance pull" of particular international legal rules. See generally

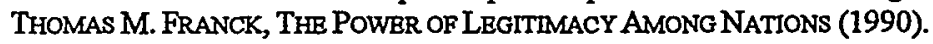

18. Franck defines rule-legitimacy as "a property of a rule which exerts a pull towards compliance on those addressed normatively, because they believe that the rule has come into being and operates in accordance with generally accepted principles of right process," that is, an internalized view of fair legal process. Id. at 24 (emphasis omitted). 
exogenously or permanently given, is overly essentialist. National identities, like national interests, are socially constructed products of culture, ideology, learning, and knowledge. As we have witnessed, nations like South Africa, Nigeria, Indonesia, Poland, Argentina, Chile, and the Czech Republic are neither permanently liberal nor illiberal, but transition back and forth from dictatorship to democracy. As Laurence Whitehead has argued, democratization has powerful international dimensions, potentially spreading from one country to another by contagion, control, or consent. ${ }^{19}$ Liberal identity analysis does not directly address the impact of compliance on democratization, and thus leaves unanswered a critical, constructivist question: to what extent does compliance with international law itself help constitute the identity of a state as law-abiding, and hence, as "liberal" or not? The notion that "only liberal states do law with one another" can be empirically falsified, particularly in such areas as international commercial law, where even rogue states like Libya tend to abide fastidiously by private international law rules on letters of credit without regard to whether they are representative democracies. Finally, like the "cultural relativist" argument in human rights, the claim that nonliberal states somehow do not participate in a zone of law denies the universalism of international law and effectively condones dealing with nonliberal states within a realist world of power politics.

In more recent writings, some liberal authors have revised their positions to say that they view liberal states not as actors, but as representative agents for various institutions and groups within civil society. These institutions and groups are more likely to engage in transborder cooperation with one another, thus predicting greater levels of transnational legal relations among liberal states. But if this is so, what it suggests is that the density of a state's interactions in the transnational legal process-not its label as liberal or illiberal-is the key to explaining its level of compliance with international law.

A fourth possible explanation- "communitarian" reasons-can be found in the English "International Society" school of International Relations, particularly in the work of Martin Wight and Hedley Bull, who traced their international origins back to the Dutch international law scholar Grotius. These theorists argue that nations obey international law because of the values of the international society of which they are a part. So, for example, the Czech Republic, Poland and Hungary now feel peer pressure to obey international law because of their community ties, now as NATO nations. The idea is that one's membership in a community helps to define how one views the obligations of that community. So, for example, when someone becomes a member of a church, they decide they will conduct their lives differently because they now view themselves as Catholic, Jewish, or Muslim. Similarly, under this view, the governments of Russia, Ukraine, and Turkey should all feel communitarian pressure to obey the European Convention on Human Rights-the "rules of their church"-because they have all now become members of the Council of Europe.

19. Laurence Whitehead, Three International Dimensions of Democratization, in THE INIERNATIONAL DMMNSIONS OF DEMOCRATIZATION 3, 5-22 (Laurence Whitehead ed., 1996) ("In the contemporary world, there is no such thing as democratization in one country, and perhaps there never was."). 
Unlike a liberal approach, this communitarian, constructivist approach at least recognizes the positive transformational effects of a state's repeated participation in the legal process. At the same time, however, the approach gives too little study to the vertical "transmission belt" whereby the norms created by international society infiltrate into domestic society. The existence of international community may explain the horizontal pressures to compliance generated among nation-states on the global plane, but it does not clarify the vertical process whereby transnational actors interact in various fora, generate and interpret international norms, and then seek to internalize those norms domestically, as future determinants of why nations obey.

Fifth and finally, there are so-called "legal process" explanations for why nations obey international law. Let me distinguish here between what I call "international legal process" or horizontal reasons for compliance, which tend to function at a government-to-government level, ${ }^{20}$ and the so-called "vertical" explanation, which focuses on the relationship between the international and the domestic legal systems. Suppose, for example, that the government of Canada wishes to urge Japan to join the global land mine treaty. Initially, the two governments will engage in government-to-government discussions at the "horizontal" nation-state level within an intergovernmental process organized by the United Nations. But at the same time, there is also a "vertical," transnational process whereby governments, intergovernmental organizations, nongovernmental organizations, and private citizens argue together about why nations should obey international human rights law. Through this vertical dynamic, international rules that are developed at a government-to-government level gradually work their way down and become internalized into domestic legal structure. Take, for example, recent legal enactments whereby global norms regarding genocide, war crimes, torture, and religious freedom have become internalized into American legal rules.

What I have just recounted is a very compressed version of a small bookshelf of political science and international law and literature. But my broader point, simply speaking, is that all five explanations-power, self-interest, liberal theories, communitarian theories, and legal process explanations-work together to help explain why nations obey international law. These five explanatory strands work together as complementary conceptual lenses to give a richer explanation of why compliance with international law does, or does not, occur in particular cases.

To clarify, let me ask the parallel question, how is domestic law enforced? What is the explanation, for example, for why we now buckle our seatbelts, even though nobody wore seatbelts only a quarter of a century ago? Of course, there are many reasons, but if you thought to explain the change in compliance, you probably would give a variety of explanations. If you organized those explanations in your own mind, they would likely fall under five headings: power or coercion, self-

20. The best exemplar of this international process view is ABRAM CHAYES \& ANTONIA HANDLER CHAYES, THE NEW SOVEREIGNTY: COMPLIANCE WITH INTERNATIONAL REGULATORY AGREEMENTS (1995), which treats the primary instrument for maintaining compliance with treaties as "an iterative process of discourse among the parties, the treaty organization, and the wider public," id. at 4 (emphasis added). 
interest, liberal theories, communitarian explanations, and legal process explanations.

Why do I now wear a seatbelt, when I never did before? First, because after the seatbelt rule issued, a lot of tickets were given out and I felt coerced to comply: a power explanation. A second factor: self-interest. People calculated that it is more rational to wear your seatbelt to avoid injury, sanction, or to gain insurance benefits. Third, the seatbelt rule acquired "rule-legitimacy" and over time developed a compliance pull. Over time, this became part of one's sense of personal identity. Individuals calculated: "If I am a law abiding person, I ought to obey the seatbelt laws." Partly, the rationale was communitarian. Authorities exhorted people with slogans such as "Seatbelts Save Lives." And fifth and finally, the seatbelt rule was inculcated via legal process. Seatbelts were required by state laws, required by federal highway standards; incorporated into federal automotive standards and became part of the way the automobiles were made. Now you cannot get into a car and drive without buckling your seatbelt without every bell and whistle and electronic voice in the car erupting into a cacophony of noise, making your life miserable until you buckle your seatbelt!

So in short, how are seatbelt laws enforced? Not by any one of these factors acting alone, but by all of them acting in combination. As we move through the five explanations-from power to legal process-we also move from external enforcement of legal rules to internal obedience with legal rules. True compliance is not so much the result of externally imposed sanctions so much as internally felt norms. In other words, as we move from external to internal factors, we also move from coercive to constitutive behavior. My children, who have been wholly socialized to wear seatbelts, have wholly internalized the norm. They view wearing seatbelts as an integral part of what it means to be a law-abiding person. As always, the best way to enforce legal norms is not to coerce action, not to impose sanctions, but to change the way that people think about themselves: whether as teetotalers, safe drivers, or regular taxpayers. In short, our prime way to enforce the law is to encourage people to bring rules home, to internalize rules inside themselves, to transform themselves from lawless into law-abiding individuals.

What does this have to do with international human rights law? I would argue that in the international arena, we are seeing the exact same process at work; a process by which norms and rules are generated and internalized and become internal rules, normative rules, and rules that constitute new nations. The best example we have is South Africa; a country which for many years was an outlaw, was subjected to tremendous external pressure and coercive mechanisms over a long period of time. Through a gradual process, South Africa has converted itself into a country that has undergone a fundamental political transformation. It has now reconstituted itself as a law-abiding country that through its constitutional processes has internalized new norms of international human rights law as domestic law.

In the same way, if the United States is attempting to encourage China to follow norms of international human rights law, the analysis above suggests the need to act at all five levels: at the level of power and coercion, to apply external and political sanctions; at the level of self-interest, to develop carrots that can be offered to China in terms of trade benefits or other kinds of economic incentives; at the level of liberal theory, to encourage Hong Kong's liberal legal identity to bubble up to the Beijing government; at the level of communitarian values, to seek to encourage 
China to ratify the International Covenant on Civil and Political Rights and other multilateral communities of international human rights observance; and finally, from a legal process perspective, to seek to engage the Chinese people and groups in civil society in a variety of international interactions that will cause them to internalize norms of international human rights law. As with the seat belt example, our goal is not simply to coerce conduct. More fundamentally, we seek to encourage a change in the nature of the Chinese political identity to reconstitute China as a nation that abides by core norms of international human rights law. In short, a theory of transnational legal process seeks to enforce international norms by motivating nation-states to obey international human rights law-out of a sense of internal acceptance of international law-as opposed to merely conforming to or complying with specific international legal rules when the state finds it convenient.

\section{How Is INTERNATIONAL HUMAN RIGHTS LAW ENFORCED?}

Against this background, how should we now understand the recent history of international human rights enforcement? Here let me contrast the two "process" stories, the one that everyone usually looks at and the one that I think people should look at. Let me contrast what I will call the horizontal story of enforcement with what I prefer: the vertical, transnational story of human rights enforcement.

\section{A. The "Horizontal" Story}

The conventional "horizontal" story about international human rights law enforcement is that international human rights law was born about fifty years ago, the product of the U.N. Charter, the Nuremberg and Tokyo war crimes trials, and the Universal Declaration of Human Rights. Under this view, the principal enforcers of human rights law have always been nation-states, who have always interacted with one another on an interstate, government-to-government level. The U.N. Charter introduced into this picture U.N. organizations and U.N. norms, which soon led to regional human rights systems as well: in Europe, the Strasbourg (Council of Europe) and Helsinki (Organization of Security and Cooperation in Europe) process; in the Americas, the Inter-American Commission and Court of Human Rights; and far less well developed regional human rights systems in Africa, the Middle East, and Asia.

In this post-war order, an international regime developed in which governments and inter-governmental organizations began to put pressure on each other-always at a horizontal, intergovernmental level-to comply with human rights, invoking such universal treaty norms as the international covenants on civil and political and economic, social and cultural rights. U.N. organizations, such as the U.N. Human Rights Commission, and treaty-based organizations, such as the U.N. Human Rights Committee, participated as intergovernmental actors in this horizontal international regime, which addressed all manner of global issues: worker rights, racial discrimination, the rights of children, women, and indigenous peoples. As we soon saw, the difficulties of this horizontal, state-to-state enforcement mechanism were legion: the rules were largely declaratory and precatory, and the few mechanisms created had virtually no enforcement. Occasionally new mechanisms would be created: judicial fora, such as the Yugoslav and Rwandan War Crimes Tribunal, or 
new executive actors, such as the U.N. High Commissioner on Human Rights, or new quasi-legislative fora, such as the Vienna Conference on Human Rights or the 1995 Beijing Women's Conference. Despite these occasional advances, the overall picture of this standard enforcement story is one of impotence, ineffectiveness, of a horizontal system where the key actors are nation-states and intergovernmental organizations, the key forums are governmental forums, and the key transactions are transactions between states and other states.

\section{B. The "Vertical" Story}

If one accepts the horizontal story as the entire picture of human rights enforcement, than the glass is indeed more than half empty. But what is the vertical picture? The "vertical" story of human rights enforcement, I would argue, is a much richer picture: one that focuses on a transnational legal process that includes a different set of actors, fora, and transactions. As I have recently argued in my Frankel Lecture, "Bringing International Law Home," the key agents in this transnational legal process are transnational norm entrepreneurs, governmental norm sponsors, transnational issue networks, interpretive communities and lawdeclaring fora, bureaucratic compliance procedures, and issue linkages among issue areas. $^{21}$

Many efforts at human rights norm-internalization are begun not by nation-states, but by "transnational norm entrepreneurs," private transnational organizations or individuals who mobilize popular opinion and political support within their host country and abroad for the development of a universal human rights norm. Such norm entrepreneurs first became prominent in the nineteenth century, when activists such as Lord William Wilberforce and the British and Foreign Anti-Slavery Society pressed for treaties prohibiting the slave trade, ${ }^{22}$ Jean-Henri Dunant founded the International Committee of the Red Cross, ${ }^{23}$ and Christian peace activists, such as America's William Ladd and Elihu Burritt promoted public international arbitration and permanent international criminal courts. ${ }^{24}$ Modern-day entrepreneurs have included individuals as diverse as Eleanor Roosevelt, Jesse Jackson, the Dalai Lama, Aung Sang Suu Kyi, and Princess Diana. These nongovernmental actors seek to develop transnational issue networks ${ }^{25}$ to discuss and generate political solutions

21. See Koh, Frankel Lecture, supra note 8, at 647-70.

22. On the transnational work of Wilberforce and the British anti-slavery movement, see generally BETTY FLADELAND, MEN AND BROTHERS: ANGLO-AMERICAN ANTI-SLAVERY COOPERATION (1972), and Ethan A. Nadelmann, Global Prohibition Regimes: The Evolution of Norms in International Society, 44 INT'L ORG. 479, 495 (1990).

23. On the work of Dunant and the International Committee of the Red Cross, which spurred the Geneva Convention of 1864 and the Hague Convention of 1899 and the movement toward codified rules of conduct in warfare, see generally PIERRE BoISSIER, HISTORY OF THE INTERNATIONAL COMMITTEE OF THE RED CROSS: FROM SOLFERINO TO TSUSHIMA (1985), and MARTHA FINNEMORE, NATIONAL INTERESTS IN INTERNATIONAL SOCIETY 69-88 (1996).

24. On the work of Ladd and Burritt, see Mark W. Janis, Protestants, Progress and Peace in the Influence of Religion, in THE INFLUENCE OF RELIGION ON THE DEVELOPMENT OF INTERNATIONAL LAW 223 (Mark W. Janis ed., 1991).

25. See Kathryn Sikkink, Human Rights, Principled Issue-Networks, and Sovereignty in Latin America, 47 INT'L ORG. 411 (1993). 
among concerned individuals at the domestic, regional and international levels, among government agencies, intergovernmental organizations, international and domestic, academics, and private foundations. Moreover, these norm entrepreneurs seek national government officials and bureaucracies concerned with the same issue areas and seek to enlist them as allies in their transnational cause. These governmental norm.sponsors-for example, U.N. Human Rights Commissioner Mary Robinson, Presidents Oscar Arias of Costa Rica, Jimmy Carter of the United States, and the Pope, to take just a few prominent ones, use their official positions to promote normative positions. These transnational actors then seek governmental and nongovernmental fora competent to declare both general norms of international law (e.g., treaties) and specific interpretation of those norms in particular circumstances (e.g., particular interpretations of treaties and customary international law rules). Such law-declaring fora thus include treaty regimes; domestic, regional, and international courts; ad hoc tribunals; domestic and regional legislatures; executive entities; international publicists; and nongovernmental organizations: law-declaring fora that create an "interpretive community" that is capable of defining, elaborating and testing the definition of particular norms and their violation. ${ }^{26}$

The next vertical step is for national governments to internalize norminterpretations issued by the global interpretive community into their domestic bureaucratic and political structures. Within national governments and intergovernmental organizations, for example, in-house lawyers and legal advisers acquire institutional mandates to ensure that the government's policies conform to international legal standards that have become imbedded in domestic law. Such institutional mandates to justify noncompliance with international legal norms may be found within the legal advising apparatus of national governments, in the Executive Branch, (e.g., the Legal Adviser's Office at the U.S. State Department), the legislature, as well as in intergovernmental organizations (e.g., the United Nations, the OAS, etc.). ${ }^{27}$

In the same way as corporations develop standard operating procedures to address new domestic mandates regarding corporate sentencing guidelines, occupational health and safety, and sexual harassment, domestic institutions adopt standard operating procedures, and other internal mechanisms to maintain habitual compliance with the internalized international norms. These institutions evolve in path-dependent routes that avoid conflict with the internalized norms. ${ }^{28}$ Thus, over time, domestic decisionmaking structures become "enmeshed" with international

26. The norm with respect to the recent genocide in Bosnia, for example, has been interpreted before such law-declaring fora as the U.N. General Assembly, the U.N. Security Council, the International Court of Justice, the International Criminal Tribunal for the Former Yugoslavia and Rwanda; the International Court of Justice, numerous scholarly groups, human rights organizations, as well as both the Congress of the United States and a U.S. federal appellate court.

27. See Antonio Cassese, The Role of Legal Advisers in Ensuring that Foreign Policy Conforms to International Legal Standards, 14 Mrch. J. INT'L L. 139 (1992); Robert C. Clark, Why So Many Lawyers? Are They Good or Bad?, 61 FoRDHAM L. REv. 275, 282 (1992) (calling lawyers "specialists in normative ordering").

28. See Mark J. Roe, Chaos and Evolution in Law and Economics, 109 HARV. L. REV. 641, 643-44 (1996) (explaining path-dependence). 
legal norms, so that institutional arrangements for the making and maintenance of an international commitment become entrenched in domestic legal and political processes. ${ }^{29}$ Gradually, legal ideologies come to prevail among domestic decisionmakers so that they seek to avoid perceptions that their actions will be perceived as domestically unlawful. Finally, strong process linkages exist across issue areas. Thus, when the United States adopts a twelve-mile limit in the ocean law area, for example, it is bound by it when dealing with refugees sailing toward U.S. shores. ${ }^{30}$ Because international legal obligations tend to be closely interconnected, even a single deviation tends to lead noncompliant nations into vicious cycles of treaty violation. These institutional habits soon lead nations into default patterns of compliance. These patterns act like riverbeds, which channel conduct along compliant pathways. When a nation deviates from that pattern of presumptive compliance, frictions are created.

By so saying, I do not mean to suggest that international legal violations never occur. I merely suggest viewing human rights enforcement through vertical, "transnational legal process" lenses can help explain why in Louis Henkin's famous phrase, "almost all nations observe almost all principles of international law almost all of the time." ${ }^{31}$ To avoid such frictions in its continuing interactions, a nation's bureaucracies or interest groups may press their leaders to shift over time from a policy of violation into one of compliance. Thus it is through this repeated cycle of interaction, interpretation, and internalization-this transnational legal process-that international law acquires its "stickiness," and that nations come to "obey" international human rights law out of a perceived self-interest that becomes institutional habit.

29. See Robert O. Keohane, Compliance with International Commitments: Politics Within a Framework of Law, International Law and International Relations Theory: Building Bridges, 86 AM. SOC'Y INT'L L. PROC. 167, 179 (1992) (discussing "institutional enmeshment," which "occurs when domestic decision making with respect to an international commitment is affected by the institutional arrangements established in the course of making or maintaining the commitment').

30. For example, Presidential Proclamation 5928, which extended the U.S. territorial sea from three to twelve miles in breadth, has since been followed throughout the U.S. executive branch as if it were internal law, and has become the basis for binding, internal Coast Guard standard operating procedures. In May 1992, the United States adopted a policy of interdicting fleeing Hartians on the high seas and repatriating them summarily to Haiti, while bringing into the United States for exclusion procedings those Haitians who entered territorial waters. In November 1992, the U.S. Coast Guard interdicted a boat containing fleeing Haitian refugees ten miles off the coast of Florida, and began making plans to repatriate the occupants. When the 1988 opinion of the Justice Department's Office of Legal Counsel was drawn to the Deputy Associate Attorney General's attention, the Coast Guard consulted with the State and Justice Departments and brought the boat into shore, rather than repatriating the occupants. See Harold Hongju Koh, Protecting the Office of Legal Counsel from Itself, 15 CARDOZO L. REV. 513, 517-18 (1993).

31. LoUIS HENKIN, How NATIONS BeHAVE 47 (2d ed. 1979). 


\section{The Pattern Illustrated}

By telling the vertical story of transnational legal enforcement, I am not saying that the "horizontal," international legal process picture is wrong. I am just saying it is incomplete. A state-to-state process account simply does not capture the full picture of how international human rights norms are currently generated, brought into domestic systems, and then brought back up to the international level. Take, for example, the recent international drive to limit the use of landmines, which began almost twenty years ago. ${ }^{32}$ Despite the development and ratification of a treaty earlier this century banning the use of landmines against civilians, an international norm against the practice had not developed.

Instead, the key step toward a global ban on landmines was taken by nongovernmental organizations in conjunction with the efforts of one U.S. senator. At the end of 1991, a group of nongovernmental activists met in Washington, D.C. and decided to create the International Campaign to Ban Landmines, which had the elimination of landmines as its goal. ${ }^{33}$ The organization enlisted the support of a governmental norm entrepreneur, Sen. Patrick J. Leahy, who introduced a measure, passed by the Congress and signed by President Bush in 1992, which prohibited the export of landmines by the United States for one year. ${ }^{34}$ Soon, the nongovernmental organizations received the support of other transnational figures, including Pope John Paul II ${ }^{35}$ Princess Diana, ${ }^{36}$ and the International Committee of the Red Cross. Frustrated with what they perceived to be a lack of progress toward a total ban through the U.N.-sponsored efforts, non-governmental organization and other countries created a new law-declaring forum, the so-called "Ottawa process," in the process enlisting another governmental sponsor, Canadian Foreign Minister Lloyd Axworthy. In the end, the Ottawa process reached agreement on the Convention on the Prohibition of the Use, Stockpiling, Production and Transfer of Anti-Personnel Mines and on Their Destruction, ${ }^{37}$ which has now been signed by more than 120 countries. Although the United States initially declined to sign the Convention, the new regime prodded the United States to enact a moratorium on the sale of landmines, to develop new technologies to aid in mine detection and demining, and to increase the amount of money that it spends on these programs to at least $\$ 100$ million per year. ${ }^{38}$ The United States further committed itself to stop using all antipersonnel mines except in Korea by 2003, and to sign the

32. For a fuller account of this campaign, see Koh, Frankel Lecture, supra note 8, at 655-63.

33. See Raymond Bonner, How a Group of Outsiders Moved Nations to Ban Land Mines, N.Y. TMES, Sept. 20, 1997, at A5.

34. See id.

35. See id.

36. See, e.g., Roxanne Roberts, From London, a Blitz with Glitz; Princess Diana Dazzles a Red Cross Benefit for Land Mine Victims, WASH. Post, June 18, 1997, at D1. Princess Diana visited landmine victims in Angola and Bosnia in early 1997. See Raymond Bonner, Pentagon Weighs Ending Opposition to a Ban on Mines, N.Y. TMMS, Mar. 17, 1996, at A1.

37. Sept. 18, 1997, 36 I.L.M. 1507 (1997).

38. See Anthony DePalma, Some See Opportunity in Global Push to Remove Land Mines, N.Y. TIMES, Dec. 7, 1997, at A14. 
treaty itself by the year 2006. Although it remains to be seen whether the Senate will soon ratify the Convention, the United States government may, within the next decade, obey the Convention by fully internalizing the Convention's norms into the governing practices of the U.S. government.

Note that under the vertical, transnational enforcement story that I have told, the central actors are not so much governmental entities as nongovernmental organizations and individuals. Today, modern transnational norm entrepreneurs include most of our recent Nobel Peace Prize winners: Burma's Aung San Suu Kyi, East Timor's Bishop Belo and Jose Ramos-Horta, Tibet's Dalai Lama, Britain's Amnesty International, and America's Martin Luther King, Jr. and Jody Willianis of the Landmines Coalition. These are people who without governmental portfolio are able to transact a different kind of process, focusing at times on creating new forums to develop new international norms. Their focus is less on the horizontal process among nation states as upon what I call "vertical" or transnational process. Their effort is to try to bring human rights law home, by trying to internalize it into domestic systems through a process of interaction, interpretation, and internalization.

How, precisely, is this internalization accomplished? In earlier work, I have sought to distinguish among social, political and legal internalization:

- Social internalization, I argue, occurs when a norm acquires so much public legitimacy that there is widespread general adherence to it.

- Political internalization occurs when the political elites accept an international norm, and advocate its adoption as a matter of government policy.

- Legal internalization occurs when an international norm is incorporated into the domestic legal system through executive action, legislative action, judicial interpretation, or some combination of the three. Some legal systems establish their receptivity to internalization of international norms through constitutional law rules regarding the extent to which treaties are or are not self-executing and rules of customary international law are or are not automatically incorporated into domestic law. ${ }^{39}$ Virtually all legal systems also have explicit mechanisms whereby executive, legislative, and judicial institutions may domesticate international norms. Thus, the landmines case exemplified the incorporation of an emerging norm of international law into U.S. law and policy largely through the executive action of the President and his agencies. Legislative internalization occurs when international law norms are embedded into constitutional norms or binding domestic legislation that officials of a noncomplying government must obey as part of the domestic legal fabric. Judicial internalization occurs when litigation in domestic courts provokes judicial incorporation of international law norms into domestic law, statutes, or constitutional norms.

The precise sequencing among political, legal, and social internalization, and among the different forms of legal internalization, will vary from case to case.

39. The national constitutions of Ireland, the Netherlands, and Italy, for example, refer to the recognition of international legal principles as a broad policy goal, thereby requiring policymakers to take account of foreign policy guidelines deriving from international law. See IRISH CONST. art. 29, § 3; GRONDWET [Constitution] [GRW. NED.] art. 90 (Netherlands); CONSTITUZIONE [Constitution] [CosT.] art. 10 (Italy). 
Sometimes an international norm is socially internalized long before it is politically or legally internalized. Thus, for example, the United States was the moving force behind the drafting and signature of the Genocide Convention in 1948, but the U.S. Senate did not formally ratify the Convention and implement it as U.S. domestic law until November 1988, long after the norm against genocide had acquired widespread social legitimacy. ${ }^{40}$ In other cases, legal norm-internalization prompted by a transnational legal process of interaction and internalization helps to trigger the process of political and social internalization of global norms. By domesticating international rules, transnational legal process thereby spurs internal acceptance of international human rights principles.

The process can be viewed as having four phases: interaction, interpretation, internalization, and obedience. One or more transnational actors provokes an interaction (or series of interactions) with another in a law-declaring forum, which forces an interpretation or enunciation of the global norm applicable to the situation. By so doing, the moving party seeks not simply to coerce the other party, but to internalize the new interpretation of the international norm into the other party's internal normative system. Its aim is to "bind" that other party to obey the interpretation as part of its internal value set. That party's perception that it now has an internal obligation to follow the international norm as it has been domestically interpreted leads it to step four: obedience to the newly interpreted norm.

Take, for example, the efforts of U.S. courts to define a U.S. law of torture under the Alien Tort Statute since Filartiga v. Pena-Irala. ${ }^{41}$ The U.S. Senate has been traditionally reluctant to ratify human rights treaties, even though the U.S. Government was one of the primary drafters of these treaties in the postwar era. The Torture Convention, the Genocide Convention, and many others lay unratified by the U.S. government despite this initial input. In 1980, beginning with Filartiga, private U.S. human rights lawyers began to bring a series of domestic lawsuits against foreign violators to promote domestic judicial incorporation of the norm against torture under a little-known eighteenth century statute, the Alien Tort Statute. Over fifteen decades, a string of U.S. courts have ruled that torture is a violation not only of international law, but also of U.S. law. In the early 1990s, these legal internalizations of the norm against torture were cited as precedents for Congress to enact a Torture Victim Protection Act, ${ }^{42}$ a statute whose drafting and enactment helped persuade skeptical officials of the Bush Administration to acquiesce in U.S. ratification of the U.N. Torture Convention. Once again, an international law norm trickled down, was internalized, and bubbled back up into new international law.

40. See Genocide Convention Implementation Act of 1987 (The Proxmire Act), Pub. L. No. 100-606, 102 Stat. 3045 (codified in 18 U.S.C. $\S \S 1091-1093$ (1994)).

41. Filartiga v. Pena-Irala, 630 F.2d 876 (2d Cir. 1980) (holding that Paraguayan human rights victims may sue Paraguayan official under Alien Tort Statute, 28 U.S.C. $\$ 1350$ (1994), in U.S. court for civil damages arising from official torture). For a theoretical analysis of this line of doctrine, see Harold Hongju Koh, Transnational Public Law Litigation, 100 YALE L.J. 2347 (1991).

42. Pub. L. No. 102-256, 106 Stat. 73 (1992) (codified at 28 U.S.C. $\$ 1350$ (1994)). 
In the United Kingdom, the issue of legislative internalization has similarly been brought to the forefront in recent years by the election of the Labour party, which promised, if elected, to incorporate the European Convention on Human Rights into United Kingdom law. This issue has been a major human rights issue in British politics since the Clement Attlee Government first ratified the Convention in the early 1950's. Since then, the Convention has been internalized in part through judicial construction. When total judicial incorporation efforts failed, a political internalization movement arose, which at this writing will shortly bring about legal internalization of the European Convention into U.K. law by an act of Parliament. ${ }^{43}$

Or, take finally the cases of the Haitian and Cuban boat people, in which my students and I were involved for several years. The United States had signed and ratified the Refugee Convention of 1951,44 a multilateral treaty at the "horizontal" level whereby it agreed not to return refugees to their persecutors. But when the Haitian refugees began fleeing to the United States in 1991, it effectively reneged on that commitment and began to return the refugees, claiming that the Refugee Convention did not bar extraterritorial repatriations. In fact, Congress had passed a statute as part of the Immigration and Nationality Act which required unequivocally that refugees not be returned to their persecutors, thus ostensibly internalizing the treaty into domestic statute. And so on behalf of the Haitian refugees my students and I brought a lawsuit in which we argued that the courts should enforce the extraterritorial nonreturn rule as a matter of U.S. domestic law. We used a "judicialization strategy" to try to reinforce the concept of legal internalization of the international norm against extraterritorial repatriations.

In the end, the Supreme Court rejected our arguments, leaving the United States legally free to continue the extraterritorial return policy. ${ }^{45}$ But other international forums, such as the U.N. High Commission on Refugees, the Inter-American Commission on Human Rights, and other bodies began to condemn the U.S. action. Various legislative efforts were made to overturn the Supreme Court's ruling, and

43. The debate over incorporation of the European Human Rights Convention is the subject of a voluminous literature. For a political history of the incorporation effort, see generally MicHAEL ZANDER, A BILL of RIGHTS? (4th ed. 1997). For a comparative study, see ANDREW Z. DRZEMCZEWSKI, EUROPEAN HUMAN RIGHTS CONVENTION IN DOMESTIC LAW: A COMPARATIVE STUDY 177-87 (1983); ASPECTS OR INCORPORATION OF THE EUROPEAN CONVENTION OF HUMAAN RIGHIS INTO DOMESTICLAW (J.P. Gardner ed., 1993); Jorg Polakiewicz \& Valerie Jacob-Foltzer, The European Human Rights Convention in Domestic Law, 12 HuM. RTs. J. 65, 65-85, 125-42 (1991). For discussion of compliance without incorporation, see DAVID KINLEY, THE EUROPEAN CONVENTION ON HUMAN RIGHTS: COMPLIANCE WITHOUT INCORPORATION (1993). See also 8(2) HALSBURY'S LAWS OF ENGLAND (4th ed. 1996) (including human rights law as part of constitutional law). For bills urging incorporation, see Human Rights Bill, as approved by the House of Lords, 577 PARL. DRB., H.L. (5th Ser.) 1726 (1997). For arguments as to why the Convention should be incorporated, see generally HUMAN RIGHTS IN THE UNITED KINGDOM (Richard Gordon \& Richard Wilmot-Smith eds., 1996); Hon. Sir John Laws, Is the High Court the Guardian of Fundamental Constitutional Rights?, 1992 PUB. L. 59; Lord Lester, The Mouse that Roared: The Human Rights Bill 1995, 1995 PUB. L. 198; Rt. Hon. Lord Browne-Wilkinson, The Infiltration of a Bill of Rights, 1992 PUB. L. 397.

44. Convention Relating to the Status of Refugees, July 28, 1951, 19 U.S.T. 6259,189 U.N.T.S. 137.

45. For analysis of the opinions, see Clawson et al, supra note 6 . 
the issue later became the subject of domestic political pressure from the AfricanAmerican community, the Congressional Black Caucus, and Trans-Africa, all of whom began to promote the notion of a safe haven for Haitian refugees. Finally, in the fall of 1994, the U.S. government changed its Haitian policy, and intervened to return the refugees. When the issue arose again the following year, with regard to fleeing Cuban refugees, the Administration first resisted, then ultimately admitted into the United States those Cuban refugees being detained at offshore refugee camps. Although the U.S. stated policy remains problematic, at this writing, the actual practice of the U.S. government has moved into greater compliance with international law.

\section{CONCLUSION}

Let me close with two thoughts. First, the foregoing analysis teaches something about our duty, as citizens, to participate in transnational legal process. It is sometimes said that someone who, by acquiring medical training, comes to understand the human body acquires as well a moral duty not just to observe disease, but to try to cure it. In the same way, I would argue, a lawyer who acquires knowledge of the body politic acquires a duty not simply to observe transnational legal process, but to try to influence it. Once one comes to understand the process by which international human rights norms can be generated and internalized into domestic legal systems, one acquires a concomitant duty, I believe, to try to influence that process, to try to change the feelings of that body politic to promote greater obedience with international human rights norms.

In that effort, every citizen counts. To this, many Americans might say, "What can one person really do? Isn't such influence beyond the capacity of any one person?" But if you look at these people I have mentioned in this lecture-Aung Sun Suu Kyi, Jody Williams, Nelson Mandela, Martin Luther King Jr.-could they have not said the same thing? In response, many students might say: "But surely, I am not such a world historical figure," to which I would answer, "You don't need to be a Nobel Prize winner to make a difference. Just look at Rosa Parks, or Linda Brown, or Fred Korematsu, ordinary people who simply said that they would not go to the back of the bus, or attend a segregated school, or live in a Japanese internment camp." In short, we need look no further than those individuals who have triggered these legal processes in our own lifetime to promote the enforcement of human rights norms.

The struggle of these individuals reminds us again of the remarkable words of Robert Kennedy, which are etched on his grave in Arlington Cemetery:

Each time a man stands up for an ideal, or acts to improve the lot of others, or strikes out against injustice, he sends forth a tiny ripple of hope, and crossing each other from a million different centers of energy and daring, those ripples build a current that can sweep down the mightiest walls of oppression and resistance.

What he is talking about, in the end, is the need for individuals to activate transnational legal process. As proof that what he says is indeed possible, one need look only at the country in which he said those words: South Africa, in 1966, a country which only three decades later has now been totally transformed by international human rights law. 
So, in closing, if my question is "how is international human rights law enforced?", my answer is simple. International human rights law is enforced, I would say, not just by nation-states, not just by government officials, not just by world historical figures, but by people like us, by people with the courage and commitment to bring international human rights law home through a transnational legal process of interaction, interpretation, and internalization. ${ }^{46}$ Thank you very much.

46. Author's note: Since I wrote these words, my life has fundamentally changed. In November 1998, I took an oath as our nation's chief human rights official. At this writing, I have now spent eight months in office, traveling to some twenty-five countries. As I have traveled from Belgrade to Beijing Colombia to Kosovo, I have become increasingly convinced of the correctness of the basic thesis I have expressed in this Lecture. Although I now spend my time as a "governmental norm sponsor," rather than as a private "transnational norm entrepreneur," I continue to witness, and to attempt to influence, the transnational legal process described herein. Ilook forward to retuming to academic life before too long, not only to finish my book manuscript on "Why Nations Obey," but also to illustrate my basic thesis with reference to my governmental experiences in Kosovo, China, Colombia, Indonesia, and elsewhere. 
